DOI: https://doi.org/10.32839/2304-5809/2019-6-70-68

UDC 821.162 .3

Kuznietsova Krystyna

Masaryk University in Brno (Czech Republic)

\title{
REFLECTION OF MODERN HUMAN IN THE CONTEMPORARY EXISTENTIAL PROSE OF CZECH WRITER JAN BALABÁN
}

Summary. In this work we will rather focus on the emerging area in the 21st century for the creation of new works in literature of the Slavic countries with a different theme and poetics that reflected the current social problems and life in the post-communist era. In this article, we generally deal with contemporary Czech authors, mainly post-communist times, their works, problems of their prose and their characters. But we prefer to engage in the work of Czech author Jan Balabán, because he stands out in the Czech literature for his short exploration, his unusual and at the same time simple characters, his impressive existential exploration. In view of his sensitive novels and the extraordinary features of the characters, we look into the world of his prose, reflection of the city in his novels and his characters.

Keywords: Jan Balabán, Czech prose, Czech novel, post-communist literature.

Кузнецова К.

Університет Масарика у м. Брно (Чехія)

\section{ВІДОБРАЖЕННЯ СУЧАСНОЇ ЛЮДИНИ В ЕКЗИСТЕНЦІЙНІЙ ПРОЗІ ЧЕСЬКОГО ПИСЬМЕННИКА ЯНА БАЛАБАНА}

\begin{abstract}
Анотація. Минуло вже тридцять років, відколи література багатьох слов'янських країн розпочала свій новий шлях, шлях складних пошуків нового і переосмислення старого. Падіння тоталітарного режиму на рубежі століття стало вирішальним поштовхом до значних змін, що здійснювались у мистецтві постмодернізмом, який руйнував межі між вигадкою і реальністю, змішуючи жанри й тексти (інтертекстуальність і метатекст), адже це було раніше забороненим, а тому перетворилось на провокаційну гру. Для більшості слов'янських літератур така зміна (або більш поширений термін «перехід») відбувалася після 1989 року, незважаючи на те, що елементи постмодерністської прози в творчості багатьох авторів проявлялися раніше. Однак, потрібно також зазначити, що постмодернізм зароджувався і був представлений в окремих слов'янських державах по-різному, таким чином викликаючи полемічну дискусію (наприклад, про існування східноєвропейського постмодернізму). Чеська літературознавець Алена Фіалова відзначає, що у новому тисячолітті в чеському середовищі постмодернізм відступає: «Бум постмодерністської експериментальної прози поступово виснажився: постмодернізм втратив відмінний характер дивовижного і провокативного жесту і став - крім інших поетик і засобів вираження - органічною частиною індивідуальних літературних стилів" [6, с. 341]. Отже, у цій роботі ми, насамперед, зосередимося на створену в XXI столітті площину для нових творів з іншою темою та поетикою, які відображають сучасні соціальні проблеми та життя посткомуністичної епохи. Коротко ми розглянемо літературну ситуацію в Чехії на переломі століть, однак зупинимось на екзистенційній прозі чеського сучасного письменника Яна Балабана, адже його творчість виділяеться талановитим наративом, який водночас вміє бути влучним і деталізованим. Для прикладу сучасної людини у прозі початку XXI століття нам прослужать його незвичайні, і в той же час прості, персонажі, його вражаюче екзистенційне спостереження. Його чутливі новели та незвичайні риси персонажів і «живого» міста, увесь світ його прози ми можемо розглядати як відображення життя людини XXI століття, і саме його герої відображають свідомість, нервозність і неспокій свого покоління в невизначеній сучасності початку нового століття.
\end{abstract}

Ключові слова: Ян Балабан, чеська проза, чеська сучасно новела, посткомуністична література, слов'янські літератури.

$\mathrm{P}$ roblem statement. In this year it will be thirty years since the literature of many Slavic countries has embarked on its new path, a path of complicated quest for a new and rethinking of the old. The fall of the totalitarian regime at the turn of the century was a decisive impetus to a significant change that was to be realized only by postmodernism, which rebelled the boundaries between fiction and reality, mixed genres and texts (intertextuality and metatext), revealed previously banned, and thus became a provocative game. For most Slavic literatures such a change (or more commonly used term transition) occurred after 1989, notwithstanding that elements of postmodern prose in the work of many authors manifested themselves earlier. However, we must also point out that postmodernism has been created and fulfilled differently in individual Slavic states (In the Czech literature, one of the first representatives of the postmodern direction is Jiř Kratochvil (My Love, Postmodern (1994) and The Confession of the Postmodernist (Śtastný Sisyfos, 2001)) as a manifestation of Czech postmodernism; in Bulharian literature such a search may be found in Georgi Gospodinov's works, Ukrainian postmodernism is represented by the creation of the literary group $\mathrm{Bu}-\mathrm{Ba}-\mathrm{Bu}$ (the most significant is the work of Yuriy Andrukhovych. The work of these authors includes distinctive postmodern elements (play with text, time and genres, the so-called "carnival", etc.), but is also marked by a distinctive poetics), thus arousing polemical discussion (e.g. on the existence of East European postmodernism). After all, in the new millennium in the Czech environment, as Alena Fialová has aptly pointed out, postmodernism is retreating: "The boom of postmodern experimental prose has been slowly exhausted: postmodernism 
has lost the hallmark of a surprising and provocative gesture and has become - besides other poetics and means of expression - an organic part of individual literary styles" [6, p. 341]. Therefore, in this work we will rather focus on the emerging area in the 21st century for the creation of new works with a different theme and poetics that reflected the current social problems and life in the post-communist era.

Analysis of recent studies and publications. The beginning of the new century brings with it the order of novelties, although they are not as sudden and distinctive as postmodernism, which has brought to the literature the feeling of "all permissiveness", and with this has encouraged the question of the value of works. Often, this is a combination of reader-intensive (elite) literature with popular, and fiction becomes a means of popular entertainment, books are considered commodities, authors seek to create a distinctive image, and seek to obtain a variety of literary prizes that will give it a guaranteed success such mainstream, pop-literature, etc.). According to A. Fialová, we can characterize the Czech prose of the new thousand-year by three generation groups:

- authors of the older generation (who started their career in the $1960 \mathrm{~s}$ ), but mostly publish older revised and supplemented works, a theme that is the political turn of the twentieth century, life under the Protectorate or individual experiences in difficult times - e.g. Jozef Skvorecký, Arnošt Lustig, Viktor Fischl;

- middle-class prose writers, divided into three subgroups for better display:

a) those whose previous work was marked by postmodernism and its elements persist in new works (mystification, experiment, mixing genres, etc.) - e.g. Jiří Kratochvil, Michal Ajvaz, Daniela Hodrová (magical realism);

b) narratives that move in particular time and deal with the question existence, lost hope, certainty and youth - eg Jan Balabán, Jiří Hájíček;

c) satirical questioning of the state of the current political unit - e.g. Michal Viewegh, Miloš Urban;

- a younger and youngest writer dealing with interpersonal relationships in their work emotional problems and searching for oneself in the world of uncertainty - e.g. Petra Soukupová, Jaroslav Rudiš, Natalie Kocábová, Jana Srámková and others [6, p. 341-344].

Another characteristic phenomenon in modern prose is the selection of exotic places for the course of action in texts (e.g. Petra Hůlová, Martin Ryšavý, Markéta Pilátová) and the recent history of the past, a view of the history of time (mostly the 40s and 80 s of the 20th century - post-war period and nostalgic memories of childhood and youth) [6, p. 341-344].

Of course, such sorting is quite generalized and does not include all the representatives of contemporary Czech prose, but it is a short outline of what processes are taking place in the literature. Certainly, in the context of greater comparative comparisons, we could find similar elements, themes and themes in various Slavic literatures, such as the similarities of depiction of the magical topos of Jiří Kratochvil or Michal Ajvaz and Ukrainian Yurii Vynnychuk, or the elements of experimental prose by Jiří Kratochvil or Jáchym Topol and Bulgarian postmodernist Georgi Gospodinov or
Ukrainian Yurii Andruchovych, etc. However, we do not have the opportunity to plunge into a deeper overview of all these phenomena and writers in this work, and therefore we choose the theme of the reflection of modern times in contemporary existential prose, especially Jan Balabán.

The research purpose. The question of livelihood writers is very often addressed, we can certainly find them in the literatures of all countries and times, but the history and transformations of societies nevertheless reflect their perception of existence. Contemporary literature is characterized by a strong search for its identity at a time of indeterminacy and uncertainty, the characters of these prose are often discarded into depressed, threatened, unadjusted to life and disordered space, where the usual dangers and traps lurk where they lead the unknown. Whether the illusion and uncertainty of identity in the work of the younger generation is largely reflected in the impossibility of finding their life path because of the lack of ambition and instruction to live, resistance to any commitment, the absence of home, as a sacred sanctuary, the impossibility of stopping anywhere, settling, organizing the environment according to their needs, requirements and pledges, middle-aged representatives are a world of people who already have some life experiences, are lifeworn, but despite their sadness and unhappiness, they continue to seek hope for improvement, always finding their way back when losing their home or arrange a new one.

Uncertainty about existence cannot be interconnected with contemporary changes in post-communist countries, and the observation of the Bulgarian poet and literary historian Plamen Dojnov is that there is a need to consider postmodern impulses in literature in Eastern European countries at the end of the 1980s, but which are always melancholic and existential [5, p. 169-171]. While the frivolity usually stands out for the desire for childhood and youth that cannot live in the new world, in the newly created state. It is a call for the constant search for the right way of life, the author with the cat's caution treads on a closed path so far, through memories and exploration, the revelation of a previously forbidden, through movement between fiction and reality, between mystical and everyday places, becomes the discoverer of a distinctive style. Such a search may be found in many contemporary Ukrainian writers. In Bulgarian prose, a pervasive example is the novel The Natural Novel ("Естествен роман", 1999) by Georgi Gospodinov. The story of a divorcing writer who, in the shadow of the tragic events of his life (wife's infidelity, departure from her, loss of home, employment, lack of life by his own life), hopes to find a way to write a proper novel, to invent a crafty structure that is easy to follow. In this novel, postmodern elements and existential questions mix, an autobiographical character tries to erase the boundary between text and life, to write his work inside another, invent a hero who is also a writer, and to create his novel he must truly experience a fictional life: "The man wanted to write a novel in which the hero was a tough guy. But everything is real. He decided to get used to the wanderers, to try to live like them for about a week. You chose a distant neighborhood to not meet acquaintances. He dropped his beard, hung a torn hat low over his eyes and became 
almost unrecognizable" [7, p. 145-146]. The strangeness in the work of Gospodinov is also the dispersion of space-time (events take place in memories that are not followed), thoughts (sudden skipping from one to the other, torn notes and misrepresentation) and types of texts (the appearance of lyrics, biblical quotes, their own and foreign poems). The author's experimentation is also confirmed by the fact that the main character in this work is spreading, thinking about the mysterious life of plants and insects, considering the appearance of a text that would write a tree or a speech, Therefore, the Natural Novel is so close to life, it changes in it and, like him, it is strange, unpredictable, intermittent and paradoxical, and therefore convincing and irrefutable. This example allows us to point out that in contemporary Slavonic literature, existential prose has its own distinctive place, and is an inevitable component for displaying the reflections of modern man and his life, the part of which is constantly searching.

Statement of the basic material and key research findings. "It is time to search and time to lose" [2, p. 9] introduces us to his book Možná že odcházíme the Czech novelist Jan Balabán with a quote from the Bible, thus outlining the world of his characters, giving them space and time just to keep searching. This author is one of the most prominent representatives of shorter prose genres in Czech literature, despite the fact that he has valuable texts of a greater scope among his works. His works are filled with individual perception and perception of the world, with deep thoughts about human being, he thinks about the fates of others from his own point of view and thus creates a unique color and style of his writing which manifests itself on all levels - in themes, characters, composition, dialogues and language. He chooses a short story for his work, allows him to better characterize the unified prototypes of contemporary life, one person is equal to one story, but often is linked by an invisible thread. Each of his stories is part of the description of the author's fictional world, and thus becomes an integral unit of the larger whole, part of the "diagnosis of the feeling of life Balaban generation's" [6, p. 461]. In many stories, the writer introduces the same character named Hans, who is often not the main character, sometimes not at all, just the memory of him or his name. This is especially true in two short story collections, Možná že odcházíme (2004) and Jsme tady (2006). Of course, writer Hans is an autobiographical figure, somehow his presence is on the show, he is somewhere away from the story, he observes his heroes from a distance, carefully inserts their fragments of dialogues, small details to come back to the pages of his books. The boundary between authorial fiction and real life fades, text and life blend together, creating a sense of reflected reality. Perhaps it is because the writer drew his inspiration from real people, from life, to hastily wrote the subject matter or the dialogue he had heard into the diary [10], which he always had. On the Czech literary record, Jan Balabán appeared with a collection of short stories Středověk (1995), which introduced him as "a new, soon unmistakable voice" [3, p. XV (579)]. Already in this first book he introduces the reader to his basic themes: "[...] the alienation, the inability to communicate among loved ones, the feel- ings of loneliness and the emptiness of one's life" [6, p. 452]. The second author's work, Boži dílo (1998), was an attempt at a novel that the writer "always wanted to write", but he calls it a poem [11]. In 2000, a collection of short stories called Prázdniny and the following attempt at the novel Černý beran was published, in 2003 the prose Kudy šel andél, in genre towards to the generation novel. However, then he returns to his favorite stories the file Možná že odcházíme (2004) and the story in ten stories Jsme tady (2006), which we will focus on in this work. The last contribution to contemporary Czech literature was the novel Zeptej se táty (2010), which Jan Balabán managed to finish just before his untimely death. The distinctive style of writing this Czech writer is in the unstoppable impression that he has been writing one book all his life, the characters are merging, and the stories are connected in a mysterious way. Perhaps this is also caused by the difficulty of adding Balaban's "non-story" texts to a certain genre classification, which has revolted many discussions, such as the best friend of the writer poet Petr Hruška: "After all, he would quickly break his literary teeth into one who would like to classify Balaban's work once according to traditional genres" [9, p. I (511)]. In the second volume of the full edition of Balaban's works, Josef Chuchma also admits in his word that he did not perceive the form in which the writer's testimony was moving and considers it to be a supranational [4, p. 567]. Even the prose writer did not include his work anywhere: "My books are actually developing more vertically than horizontally; I do not map them. The only development I'm trying to do is go further apart, from autobiography, [...]. I perceive writing as a process, not as writing something. It's my way of organizing the world" [11]. The main themes of the stories of Jan Balabán, as mentioned above, are the dramatic fates of people who get into difficult life situations (but more often than in the mental), episodic fragments of foreign lives at the moment of their breaks, at the moment of their existential trials. But the author always looks at the development of events and the actions of these characters with caution, without any condemnation and criticism, rather sympathetic to them, or as it is in most cases merely an observer. Another "basic theme of the stories is the examination: an attempt to describe and diagnose the human life feeling at the beginning of the twenty-first century" [6, p. 457]. Returning to the past is a link on the path to understanding and finding yourself. A time-lapse view of childhood and youth (which took place in bad times) partly brings clarity to the broken mosaic of these people's life or at least remind them of their history. Retrospectives fluctuate, from ancient times (life of grandparents) to recent ones (parents' lives, memory of their childhood and youth). Collection Možná že odcházime them all filled with memories of narrators and performers, from the first short stories Emil, Bethezda (years of communist), and into deeper times, as is the story of Gabriel, which basically composes all of the dialogues, a snippet of talk of which we learn the whole life of man. The flow returns in time are also in stories from the book Jsme tady, we learn about the whole family of Patricia from the story Vděčna smrt, or the agitated thoughts of Hans, 
which makes him remind of the city's scars in the Most prose etc. memories and heaviness, one can feel that he is still breathing and still alive.

In Balaban's short stories are people we can meet on the bus, in the queue, at the station, their faces are marked by the burden of bad luck. The author never engages many people in the story, usually one, a maximum of three, yet other names emerge from her memories and dialogues that remain mere shadows but complement the idea of the narrator. A frequent topic of the writer's testimony is a failed marriage that forces the protagonist to continually think about the unpredictability and paradox of human being. A good example is the story Edita, Kolotoč or Uršula from the book Možná že odcházíme, about married couples who experience a turn in their relationships. Divorce or other wreckage that leads to the sudden loneliness of a person who has had home and family so far, and suddenly loses hope: "There is a boat on the waves, a fast-modern motorboat. There's a single figure on him, a man, a sailor. I've never seen him, and I'll never see him again, because no boat can land here, just crash. You are waving and screaming in vain, giving no sign in vain, you cannot reach my shore" [2, p. 15]. However, the character crisis in the author's texts is not just about interpersonal relationships (men and women, parents and children), but also middle-aged people. Obviously, the selection fell to the forties and fifties because Jan Balabán understood or at least tried to understand them, but also because they excel in the 21 st century, as Lenka from the Triceratops story says: "It seemed to her that Hans's friends didn't take the present twenty-one too seriously. She's not too serious either. She recalled Cosmo Girl, who had recently seen her younger cousin. How to be in? These men seem to think about how to be out. [...] admitted that she just liked it. Herself is somewhere in between and being between [...] will not last long" [2, p. 117].

Among the figures of Jan Balabán's shorter prose are representatives of various social facilities from intellectuals (teachers, painters, translators, etc.) to people who live on social welfare, wasting their alcohol drinking days and searching for light earnings, but they are always robbed of their own lives, fate sends them in the wrong direction from which it is difficult to return. This is perhaps the case in the story Uršula about an intellectual who once worked at the Faculty of Philosophy, but decided to devote herself to the family, while in the Kolotoč, singer Alice and photographer Bednár chose a career instead of children, or at Bethez$d a$ a CD retailer who left his studies and could be a teacher, etc. The situations that lead to breakthroughs, the change of worldview, and especially to their lives, are depicted by Balaban not in vain, in this way they try to show that life choices and pathways are not always right, nor can they be, but we always have the opportunity to look back, not losing the limits of mundane and trying to change. The frequent protagonists are the loners, immersed in their own mental contemplation, such images are filled with the whole book Možná že odcházime and Jsme tady, somewhat lonely even in the presence of others. We can find the mystery of these prototypes even in its anxieties, not only from the uncertainty and loss, but also from the strange experience of fear, which is located on the border of terror and shielding, e.g. from birds (A ptáci taky), from naked people (Gabriel) or from desserts (Triceratops) etc. Also, a special feature of the space-time of Balaban's fictional worlds is the constant movement of individuals, or as stated by A. Fialová a "non-story story" [8, p. 476]. The description of the characters is usually indirect, there is no description of her appearances. Topos of the city, industrial Ostrava, strengthens the idea and brings a distinctive color to the text space. We feel the author's love for this double city, where ruins, factories, pawnshops and playrooms with the rest of the forests coexist. In excerpts, however, the enthusiasm of the Beskydy nature permeates, a positive relationship to the mountain and rural landscape, which is evident in the strong lyrization of the utterance.

The language of Jan Balabán's prose is also very distinctive, despite the fact that mostly the er-form prevails, he likes to shoot various types of testimony. As well as the style of language - from highly intellectual to colloquial, delinquent to vulgar. In this regard, Alena Fialová presents two specifics of Jan Balabán: 1. Language - intellectual, lyrical in descriptions of feelings and landscapes, instructive in thought over evangelical faith, and suddenly expressive, plain and folk. 2. Storytellers situation alternating er-form, their-form and turning to the reader (du-form) [6, p. 457-463]. However, the sharp change in the narrator's position is mainly due to the fact that the writer does not claim to be a voice that speaks for another, and therefore recedes and passes on the word to his characters. Since the passages written in their form give the impression of autobiography, sensitivity and approaching lyricism. The characteristics of this Czech writer should also be noted in his art of describing details that bring us even closer to reality. For example, in the Bethezda story: "Ludvík suddenly noticed how fragile the man was. He had dirty hands, nails, ankles, dirty cuffs. It was not a good dirt of strong hands. This dirt stuck her thin skinny hands like a sickness" [2, p. 33] or in Do chodníčka: "Planks on the floor in the room black as a shoe, a spirit on the bed of soot, a chainsaw on the table, a bottle of oil, a bottle of liquor, ashtrays, cans, mugs from the coffee shop. Spiderwebs on the walls, gray windows from dust [...]" [2, p. 75-76]. Such insights can be found in descriptions of landscapes and interiors, as well as in the appearance of characters, not only in their suits, but also in their faces: "Everything is possible in a multi-purpose world, only those wrinkles around the eyes and mouth, those cracks, bruises and scars that it hurts somewhere near the heart, they will become deeper" [2, p. 45].

Conclusions. In his characters, the writer is always looking for something to look at the real „human", trying to find the right linguistic and narrative locations to characterize the state of today's world in the most accurate and detailed way. By his work, "he defined the situation of many of today's $50 \mathrm{~s}$, people who lived half their productive lives in conflict with the violent and undermining regime, and the other live in disillusionment with the way the world is - for appearances' sake free - furnished" [6, p. 463]. And human relationships in this world have always been and will be an unsolvable task, a bundle of tangled threads, the stories of Jan Balabán 
just give us one more chance to see behind a closed door, even though the reader is not always taught to learn, always at least knows he is not alone. Since his work is thus approaching a generational testimony that he can summarize in one paragraph: "There will be only shadows, solid, well-defined rectangles thrown onto the cracking asphalt of the street that will be patched and patched over the years by as- phalters until you know what the patch is and what the original path is. And that is the life that will not be able to get a new coat in all these years" [2, p. 23], in which we confirm that the prose of the Czech writer Jan Balabán can be regarded as a reflection of the life of a man of the 21st century, and his characters reflect the conscience, nervousness and restlessness of his generation in an uncertain today.

\section{References:}

1. Balabán, Jan. Jsme tady. Příběh v deseti povídkách. Brno : Host, 2006.

2. Balabán, Jan. Možná že odcházíme. Brno : Host, 2011.

3. Balabán, Jan. Romány a novely. Dílo II. Brno : Host, 2011.

4. Chuchma, Josef. Od sebe k druhým a zpět k sobě (doslov). In: Balabán, Jan: Romány a novely. Dílo II. Brno : Host, 2011.

5. Dojnov, Plamen. B'lgarskata poezija v kraja na 20 vek. Čast vtora. Sofija : Prosveta, 2007.

6. Fialová, Alena (ed.). Vsouřadnicích mnohosti. Ceská literatura první dekády jednadvacátého století v souvislostech a interpretacích. Praha : Academia, 2014.

7. Gospodinov, Georgi. Estestven roman. Plovdiv : Izdatelska k’šta Žanet45, 2005.

8. Hruška, Petr (ed.). V souřadnicích volnosti: česká literatura devadesátých let dvacátého století v interpretacích. Praha : Academia, 2008.

9. Hruška, Petr. Vážně (doslov). In: Balabán, Jan: Povídky. Dílo I. Brno : Host, 2010.

10. Iwashita, Daniela, Plzák, Michal (ed.): Honzo, ahoj! Setkání s Janem Balabánem. Praha : Kalich, 2011.

11. Možná nejsme sami. Rozhovor Daniely Iwashity s Janem Balabánem z roku 2004. Lidové noviny. URL: http://www.lidovky.cz/mozna-nejsme-sami-rozhovor-s-janem-balabanem-z-roku-2004-pfd/kultura.aspx?c= A101217_130633_ln_kultura_glu 